\title{
How Many Phonemes Does the English Language Have?
}

\author{
Aldo Luiz Bizzocchi \\ Universidade de São Paulo, Núcleo de Apoio à Pesquisa em Etimologia e História da Língua Portuguesa, $R$. \\ Dr. Albino Rodrigues de Alvarenga, 80, São Paulo SP - Brazil \\ *Corresponding Author: Aldo Luiz Bizzocchi, Universidade de São Paulo, Núcleo de Apoio à Pesquisa \\ em Etimologia e História da Língua Portuguesa, R. Dr. Albino Rodrigues de Alvarenga, 80, São Paulo SP \\ - Brazil
}

\begin{abstract}
Most phonology textbooks claim that the phonological system of the English language is composed of 44 phonemes, of which 24 are consonants (actually, two are semivowels) and 20 are vowels. Yet, this number results of a misinterpretation of the English vowel system, since several authors consider clusters of sounds (diphthongs and pseudo triphthongs) as single phonemes, as well as combinatorial allophones of the same phoneme as distinct phonemes. By employing the definitions of phoneme, phone, and allophone, together with the criteria of commutation and substitution formulated by Trubetzkoy and the phonologists of the Prague School, allied to the concept of neutralisation and archiphoneme of the traditional structural phonology, it is possible to prove that the real number of phonemes of English is actually 35. This paper intends to revise the English phonological system, especially regarding vowels, by using the same methodology employed to describe the phonology of other languages, such as French, for example. As a result, we will try to demonstrate that the current phonological description of the English language has a lot of idiosyncratic and, therefore, a new view of this system will reflect on the phonemic transcription of words made by dictionaries, making it simpler.

Keywords: English phonology; English vowel system; English vocalism; number of phonemes; allophone; neutralisation; archiphoneme; Received Pronunciation; General American; English varieties.

Abbreviations: AmE: American English

BrE: British English

Fr.: French

GA: General American

It.: Italian

NE: New English

OE: Old English

Port.: Portuguese

RP: Received Pronunciation
\end{abstract}

\section{INTRODUCTION}

The number of English phonemes varies from one variety to another, but in general the language is considered to have between 22 and 24 consonants (the difference is due to two units that in some systems are considered phonemes and in others not), two semivowels and 20 vowels in the British variety (BrE). In the American variety (AmE), 15 to 19 vowels are usually considered. Only this data suffices to show that, if the number of consonants seems to be a point of agreement among specialists, the determination of the number of vowels is subject to the individual interpretation of the researcher. In fact, there are several possible criteria to individualise the distinctive units of a language, from those more strictly linked to the phonetic aspect to those of a purely functional nature.

In any case, the spirit of phonological analysis, as formulated by its early researchers, such as Nikolai Trubetzkoy and his colleagues in the Prague Linguistic Circle, excels at simplicity (of all possible descriptions, one should always choose the simplest) and intuitiveness (the phoneme must be an abstraction of the sounds of speech).

However, the usual description of the English phonological system, which includes 44 phonemes, considers as single vowel phonemes several vowel clusters (diphthongs and, in certain cases, even pseudotriphthongs), as well as treats as distinct phonemes what can be easily proved to be combinatorial variants (allophones) of the same phoneme.

English has precisely the peculiarity of making a single vowel or semivowel sound in different ways depending on the context where it lies. The tendency of the predominant phonological descriptions is 
to treat each unit of phonetic realisation (i.e. each phone) with its respective context of occurrence as an indivisible unit. For example, the cluster [eI] of late, although formed by two phones, [e] and [I], is

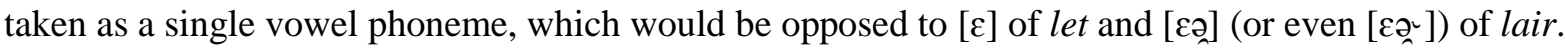

The perspective of analysis proposed here increases very little the number of combinatorial allophones (what is, by the way, perfectly reasonable, since the number of allophones, including free and combinatorial ones, is naturally large due to the plethora of regional and national varieties of the language), but reduces the number of phonemes, restricting them to the really distinctive minimal units, thus to units represented at the level of the concrete realisation by a single phone. This perspective represents a great economy in terms of the linguistic cost vs. yield relation, which is the very spirit of the phonological description of a language, besides making it much simpler.

But before proceeding, we should recall that the analysis of the signifier of the linguistic sign - as well as the analysis of every linguistic element - takes place at three levels, as defined by Coseriu [1], namely, system, norm, and speech. At the level of concrete speech what we have is sound as an acoustic phenomenon, only analysable and describable by means of graphs produced by spectrograms. Therefore, when a linguist analyses the sounds of speech, what he or she really studies are not the endless and unrepeatable concrete acoustic realisations that speakers produce in their dayto-day life, but abstractions made from these realisations, that is, patterns of pronunciation, units of norm called phones, which, although numerous, are not infinite like concrete sounds, physically detectable and recordable, and which, being units of norm, vary according to factors such as the speaker's place of origin, age, sex, and schooling, among other variables.

In turn, at the level of the system, we can say that all these phones, some combinatorial (that is, dependent on the phonological context where they lie), others free (that is, dependent only on the factors mentioned above), are distributed in a number of minimal units distinguishing meanings that are the phonemes, the number of which in principle must be the same for all speakers of the language (or at least for all speakers of a particular national variety of the language).

The standard test to determine whether or not two phones represent the same phoneme is the so-called commutation vs. substitution test: if the exchange of one phone by another, maintaining all other phones of the word signifier, in all words in which both can occur, does not cause a change of meaning, we say that these two phones are allophones of the same phoneme, in which case the exchange is called substitution. Likewise, if two phones never occur in the same phonological contexts, that is, they have complementary distribution, we also say that they are allophones of the same phoneme.

When the exchange of a phone for another in the same conditions described above causes the change of meaning, we say that these phones represent two distinct phonemes and, therefore, constitute a minimal pair. In this case, the exchange is called commutation. For example, [f] and [v] are the normlevel realisations of the distinct phonemes /f/ and /v/ because fat and leaf mean things other than vat

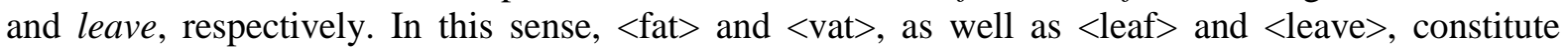
minimal pairs.

When two or more phones are usually opposed (i.e. represent distinct phonemes) in most contexts, but in some of them this opposition does not take place, we say that there is neutralisation of the phonemes that they represent. For example, we know that $[\mathrm{s}]$ and $\left[\int\right]$ represent different phonemes because see and ass are different from she and ash. However, the exchange of the one by the other does not change the meaning when they are in final position of word and the next word begins with [j], as in I miss you, which can be pronounced both as [a $\mathrm{mIs}$ ju:] and as [a $\mathrm{mI} \int \mathrm{ju}:$ (especially in the USA). The result of neutralisation is the emergence of an archiphoneme, a unit that brings together the distinctive features of the neutralised phonemes. In the above example, the neutralisation of $/ \mathrm{s} /$ and /J/ results in archiphoneme /S/.

\section{THE ENGLISH PHONOLOGICAL SYSTEM IN THE MAINSTREAM APPROACH}

Table 1 shows the 44 English phonemes as defined in what I will henceforth call the 'mainstream approach', that is, the predominant one in current English phonology textbooks. The inventory of phonemes is based on the two main varieties of English, the British (BrE), based on the Received Pronunciation (RP), and the American (AmE), based on General American (GA). The representation of the phonemes in this table uses the two usual systems: one, used in most American dictionaries; the other, used in most British dictionaries. 
How Many Phonemes Does the English Language Have?

Table1. The English phonological system according to the mainstream approach

\begin{tabular}{|c|c|c|c|c|c|c|c|c|c|}
\hline \multicolumn{5}{|c|}{ Consonants and semivowels } & \multicolumn{5}{|c|}{ Vowels } \\
\hline GA & RP & Allophones & Context & Example & GA & $\mathbf{R P}$ & Allophones & Context & Example \\
\hline \multirow{3}{*}{$/ \mathrm{p} /$} & \multirow{3}{*}{$/ \mathrm{p} /$} & \multirow[t]{3}{*}[\mathrm{p}^{\mathrm{h}}]{$[2],[3]$} & \multirow{2}{*}{$\begin{array}{l}\text { word onset, before stressed } \\
\text { vowels }\end{array}$} & \multirow{2}{*}{$\begin{array}{l}\text { path, } \\
\text { campaign }\end{array}$} & \multirow{3}{*}{$/ \breve{a} /$} & \multirow{3}{*}{$/ \mathrm{a} /{ }^{1}$} & [æ] & $\begin{array}{c}\text { except in } \\
\text { diphthong /aj/ }\end{array}$ & cat, out \\
\hline & & & & & & & [a] & diphthong /aj/ & by \\
\hline & & & after /s/, end of syllable & $\begin{array}{l}\text { spend, } \\
\text { gap }\end{array}$ & & & [a] & $\begin{array}{l}\text { diphthongs /aj/ } \\
\text { and /aw/ }\end{array}$ & by, out \\
\hline \multirow{3}{*}{$/ \mathrm{t} /$} & \multirow{3}{*}{$/ \mathrm{t} /$} & $\begin{array}{c}{\left[\mathrm{t}^{\mathrm{h}}, \mathrm{t}^{\mathrm{h}}\right][2],} \\
{[3]}\end{array}$ & $\begin{array}{l}\text { word onset, before stressed } \\
\text { vowels }\end{array}$ & tap, contain & \multirow{3}{*}{$/ \overline{\mathrm{a}} /$} & \multirow{3}{*}{ /eI/ } & \multirow{3}{*}[\mathrm{eI},\varepsilon\mathrm{I}]{} & \multirow{3}{*}{$\begin{array}{l}\text { except before /r/ } \\
\text { and /R/ }\end{array}$} & \multirow{3}{*}{ play, state } \\
\hline & & {$[\mathrm{t}, \mathrm{t}][2],[3]$} & after /s/, end of syllable & stop, hat & & & & & \\
\hline & & {$[\mathrm{r}]$} & $\begin{array}{c}\text { after a stressed vowel and } \\
\text { before an unstressed vowel } \\
\text { (especially GA) }\end{array}$ & better, petal & & & & & \\
\hline \multirow{2}{*}{$/ \mathrm{k} /$} & \multirow{2}{*}{$/ \mathrm{k} /$} & {$\left[\mathrm{k}^{\mathrm{h}}\right][2],[3]$} & $\begin{array}{l}\text { word onset, before stressed } \\
\text { vowels }\end{array}$ & $\begin{array}{c}\text { cat, } \\
\text { because }\end{array}$ & \multirow{2}{*}{ /âl } & \multirow{2}{*}{ /eə/ } & \multirow{2}{*}[\varepsilonə,\text{,GA}\varepsilon^{\llcorner}]{} & \multirow{2}{*}{ before /r/ and /R/ } & \multirow{2}{*}{ fairy, where } \\
\hline & & {$[\mathrm{k}]$} & after /s/, end of syllable & $\begin{array}{l}\text { scan, } \\
\text { lack }\end{array}$ & & & & & \\
\hline$/ \mathrm{ch} /$ & $/ \mathrm{t} \mathrm{t} /$ & {$\left[\mathrm{t} \int, \mathrm{t} \int^{\mathrm{w}}\right]$} & all contexts & c heap, watch & /ä/ & /a:/ & {$\left[a:, G A a, a^{-}\right]$} & all contexts & father, star \\
\hline$/ \mathrm{h} /$ & $/ \mathrm{h} /$ & [b] & all contexts & bad dab & / & le/ & {$[\varepsilon]$} & all contexts & red, play \\
\hline $10 /$ & 70/ & [0] & all contexts & оad, dá & (e/ & ter & [e] & in diphthong /ej/ & play \\
\hline & & {$[\mathrm{d}, \mathrm{d}]$} & all contexts & dab, bad & & & & except before $/ \mathrm{r} /$ & \\
\hline$/ \mathrm{d} /$ & $/ \mathrm{d} /$ & {$[\mathrm{c}]$} & $\begin{array}{l}\text { after a stressed vowel and } \\
\text { before an unstressed vowel } \\
\text { (especially GA) }\end{array}$ & ladder, pedal & /e/ & /1:/ & [1:, GA 1] & and /R/ & tee, clean \\
\hline & & & & & & & {$[\mathrm{I}]$} & all contexts & pit \\
\hline /g/ & /g/ & [g] & all contexts & gap, log & $/ \tilde{\mathbf{1}} /$ & /I/ & [i] & $\begin{array}{c}\text { before vowels and } \\
\text { in final position }\end{array}$ & $\begin{array}{l}\text { geology, } \\
\text { happy }\end{array}$ \\
\hline$/ \mathrm{j} /$ & $/ \mathrm{d}_{3} /$ & {$\left[\mathrm{d} 3, \mathrm{~d}^{\mathrm{w}}\right]$} & all contexts & job, ridge & $/ \overline{\mathbf{1}} /$ & /aI/ & [aI, al] & except before /R/ & by \\
\hline /f/ & /f/ & /f/ & all contexts & face, staff & /î/ & /Iə/ & [I] & before $/ \mathrm{r} /$ and $/ \mathrm{R} /$ & fear, fearing \\
\hline$/$ th/ & $/ \theta /$ & {$[\theta, \mathrm{t} \theta]$} & all contexts & thing, both & $/ \breve{\mathrm{o}} /$ & $/ \mathrm{p} /$ & {$[\mathrm{p}, \mathrm{\rho}, \mathrm{GA} \mathrm{a}]$} & except before /R/ & pot, sorry \\
\hline$/ \mathrm{s} /$ & $/ \mathrm{s} /$ & {$[\mathrm{s}]$} & all contexts & soap, stress & $/ \overline{\mathbf{o}} /$ & /əo/ & 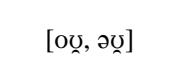 & $\begin{array}{c}\text { except before } / \mathrm{r} / \\
\text { and } / \mathrm{R} / /^{2}\end{array}$ & low \\
\hline$/ \mathrm{sh} /$ & /g/ & {$\left[\int, \int^{w}\right]$} & all contexts & shell, wash & /ô/ & /o:/ & $\begin{array}{c}{[\mathrm{o}, \mathrm{RP} \text { o:, GA }} \\
\text { o] }\end{array}$ & all contexts & caught, all \\
\hline$/ \mathrm{h} /$ & $/ \mathrm{h} /$ & {$[\mathrm{h}]$} & word onset, after consonants & have & doi/ & / & [0] & except before $/ \mathrm{r} /$ & tov \\
\hline ini & $\pi 111$ & {$[\mathrm{~h}, \mathrm{~h}]$} & between vowels & behave & 1017 & / Jil & {$\left[\begin{array}{lll} \\
{[}\end{array}\right]$} & and /R/ & 10y \\
\hline$/ \mathrm{v} /$ & $/ \mathrm{v} /$ & {$[\mathrm{v}]$} & all contexts & vat, cave & /oo/ & $/ \mho /$ & {$[\mho]$} & $\begin{array}{l}\text { except in word } \\
\text { onset }\end{array}$ & foot, pull \\
\hline$/ \mathrm{dh} /$ & /ð/ & [ð, dð] & all contexts & $\begin{array}{c}\text { then, } \\
\text { other, booth }\end{array}$ & /oo/ & /u:/ & {$[\mathrm{u}, \mathrm{u}:, \mathrm{GA} \mathrm{u}]$} & $\begin{array}{c}\text { except before /r/ } \\
\text { and /R/ }\end{array}$ & food, super \\
\hline $\mid \mathrm{z} /$ & $\mid \mathrm{z} /$ & {$[\mathrm{z}]$} & all contexts & zebra, gaze & $/ \breve{\mathrm{u}} /$ & $/ \Lambda /$ & {$[\Lambda, \mathfrak{e}]$} & $\begin{array}{l}\text { except in word } \\
\text { final }\end{array}$ & hut, undo \\
\hline /zh/ & $\mid 3 /$ & {$\left[3,3^{\mathrm{w}}\right]$} & all contexts & genre, vision & $/ \overline{\mathrm{u}} /$ & /av/ & {$[\mathrm{a}, \mathrm{N}, æ 0]$} & except before /R/ & out \\
\hline$/ \mathrm{m} /$ & $/ \mathrm{m} /$ & [m] & all contexts & map, dam & $/ \hat{\mathrm{u}} /$ & /3:/ & {$[3:, \mathrm{GA} 3, \infty]$} & all contexts & $\begin{array}{c}\text { furry, hurt, } \\
\text { hors-doeuvre }\end{array}$ \\
\hline$/ \mathrm{n} /$ & $/ \mathrm{n} /$ & {$[\mathrm{n}]$} & all contexts & nap, man & - & /ひə/ & [णə] & before /r/ and /R/ & pure, fury \\
\hline$/ \mathrm{ng} /$ & $/ \mathrm{y} /$ & {$[\mathrm{y}]$} & only after vowels & hang & /ə/ & /ə/ & {$[\partial, \mathrm{i}]$} & $\begin{array}{l}\text { unstressed } \\
\text { syllable }\end{array}$ & $\begin{array}{c}\text { about, super, } \\
\text { apron }\end{array}$ \\
\hline & & {$[1]$} & before vowels (especially RP) & low & & & & & \\
\hline /1/ & /1/ & [1] [4], [5] & all contexts & fall, felt & & & & & \\
\hline$/ \mathrm{r} /$ & $/ \mathrm{r} /$ & $\begin{array}{l}{\left[\mathrm{I}, \mathrm{I}^{\mathrm{w}}, \mathrm{r}, \mathrm{r}\right]} \\
{[6]}\end{array}$ & $\begin{array}{c}\text { before vowels (RP), all contexts } \\
\text { (GA) }\end{array}$ & red, pray & & & & & \\
\hline & & {$\left[\mathrm{I},{ }^{\mathrm{I}}, \mathrm{U}\right]$} & after vowels (GA) & star, start & & & & & \\
\hline$(/ \mathrm{wh} /)$ & $(/ \mathrm{hw} /)$ & {$[\mathrm{hw}, \mathrm{M}, \mathrm{w}]$} & word onset & what & & & & & \\
\hline$(/ \mathrm{kh} /)$ & $(/ \mathrm{x} /)$ & {$[\mathrm{x}]$} & only in foreign words & $\begin{array}{c}\text { loch, } \\
\text { chutzpah }\end{array}$ & & & & & \\
\hline$/ \mathrm{y} /$ & $/ \mathrm{j} /$ & [j] & before vowels & yes & & & & & \\
\hline$/ \mathrm{w} /$ & $/ \mathrm{w} /$ & [w] & before vowels & well & & & & & \\
\hline
\end{tabular}

${ }^{1}$ The vowel /a/ tends to be pronounced as [a] by many British speakers nowadays even in contexts other than the diphthongs /aj/ and /aw/. Conversely, many American speakers tend to pronounce [æ] closer and tenser, making sometimes the distinction between [æ] and $[\varepsilon]$ (that is, between /a/ and /e/) difficult to perceive.

${ }^{2}$ In AmE, /ō/ can also occur before /r/, as in four [fou I] $]$. 
The alleged phonemes /hw/ and / $/$ have been included in Table 1 because they are sometimes considered to be an integral part of the English phonological system. However, /hw/, even when pronounced as a single phone [ $\mathrm{M}$ ] (a voiceless labiovelar fricative [7], [8], [9] or approximant [10]), is phonologically analysed as the cluster of phonemes $/ \mathrm{h} /$ and $/ \mathrm{w} /$. In favour of this position is the fact that most of the speakers who distinguish between the pronunciation of whine and wine realise $\langle w h\rangle$ as $[\mathrm{hw}]$ and not as $[\mathrm{M}]$. In addition, historically $\langle\mathrm{wh}\rangle$ comes from $\langle\mathrm{hw}\rangle(\mathrm{OE}$ hwat $\rangle \mathrm{NE}$ what $)$. A similar phenomenon occurs with the pronunciation of $\langle\mathrm{hu}\rangle$ in huge [çu:d3], which is nonetheless phonologically analysed as /hju:dz/ [11].

In turn, the voiceless velar fricative [x] occurs in words such as loch, which is usually pronounced [lox] in Hiberno-, Scottish, South African and Welsh English - but as [lok] in the other varieties. Nevertheless, loch is a loanword from Scots, which, strictly speaking, is another language, although many consider it a dialect of English. In actuality, a dialect is a non-standardised language, but still a language, therefore something different from a simple variety. In this sense, British English and American English are varieties of English, just as Californian and New Yorker are varieties of American English. In contrast, Scots is a language independent of English, with its own vocabulary, grammar, and spelling, and today, already having its standardised written form, it cannot even be considered as a mere dialect any longer.

Now if loch is strictly a foreign word, pronouncing it as [lpx] is the same as pronouncing cordon bleu as [kрь' $\mathrm{d}$ ว blø]: these are words that, although they are part of the English lexicon, are not fully nationalised and, therefore, many speakers pronounce them in a foreign fashion.

To this list of phonemes, we can add the archiphonemes presented in Table 2, in which the symbol represents neutralisation and $\varnothing$ stands for the zero phoneme, that is, the absence of sound.

Table2. English vocalic and consonantal archiphonemes

\begin{tabular}{|c|c|}
\hline Archiphoneme & Context of neutralisation \\
\hline$/ \mathrm{E} /=/ \mathrm{\partial} / \sim \varnothing[12],[13],[14]$ & In unstressed syllable: battery, wooden \\
\hline$/ \mathrm{I} /=/ \mathrm{\partial} / \sim / \mathrm{I} /$ & In unstressed syllable: animal \\
\hline$/ \mathrm{E}^{\prime} /=/ \mathrm{E} / \sim / \mathrm{I} /=/ \mathrm{\partial} / \sim / \mathrm{I} / \sim \varnothing$ & In unstressed syllable: ordinary, Latin \\
\hline$/ \mathrm{R} /=/ \mathrm{r} / \sim \varnothing$ & $\begin{array}{l}\text { In word-medial position: } \\
\text { /r/ or } \emptyset \text { before consonants: part } \\
\text { In word-final position: } \\
\text { /r/ or } \emptyset \text { before consonants: far from } \\
\text { /r/ before vowels: far away }\end{array}$ \\
\hline$/ \mathrm{T} /=/ \mathrm{t} / \sim / \mathrm{t} / \sim \varnothing$ & $\begin{array}{l}\text { In word-final position: } \\
/ \mathrm{t} / \text { or } / \mathrm{t} / \text { before } / \mathrm{j} / \text { : got you } \\
/ \mathrm{t} / \text { or } \emptyset \text { after } / \mathrm{n} / \text { and before vowels: in front of } \\
/ \mathrm{t} / \text { before the other phonemes and in absolute final position }\end{array}$ \\
\hline$/ \mathrm{D} /=/ \mathrm{d} / \sim / \mathrm{d} \mathrm{J} / \sim \varnothing$ & $\begin{array}{l}\text { In word-final position: } \\
/ \mathrm{d} / \text { or } / \mathrm{d} / / \text { before } / \mathrm{j} /: \text { and you } \\
/ \mathrm{t} / \text { or } \emptyset \text { after } / \mathrm{n} / \text { and before vowels: on and on } \\
/ \mathrm{d} / \text { before the other phonemes and in absolute final position }\end{array}$ \\
\hline$/ \mathrm{S} /=/ \mathrm{s} / \sim / \mathrm{J} /$ & $\begin{array}{l}\text { In word-final position: } \\
/ \mathrm{s} / \text { or } / \mathrm{S} / \text { before } / \mathrm{j} /: \text { miss you } \\
/ \mathrm{s} / \text { before the other phonemes and in absolute final position }\end{array}$ \\
\hline$|\mathrm{Z} /=| \mathrm{z} / \sim / 3 /$ & $\begin{array}{l}\text { In final position: } \\
\text { /z/ or /3/ before } / \mathrm{j} / \text { : is you } \\
\text { /z/ before the other phonemes and in absolute final position }\end{array}$ \\
\hline
\end{tabular}

Finally, the mainstream approach usually considers the existence of the triphthongs /eıə/, /агə/, /əгə/, /avə/ and /əvə/ (or /ovə/). Actually, these clusters are best analysed as sequences of two phonemes (one diphthong plus /ə/). In our reinterpretation of this system, we will see that, in fact, these are three phonemes, although in certain varieties some of them may sound like hiatuses or even monophthongs:

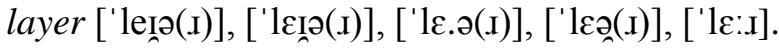

\section{REINTERPRETING THE MAINSTREAM SYSTEM}

As we said, there is no objection to English consonantism; my disagreement refers to vocalism and semivocalism. Therefore, the phonological description proposed here maintains the consonant phonemes of the mainstream system, but reanalyses vowels and semivowels.

\section{Vocalism in the BrE variety}

British English actually has 11 vowel phonemes, six short and five long, namely (Table 3): 
How Many Phonemes Does the English Language Have?

Table3. British English vowel phonemes in the new approach

\begin{tabular}{|c|c|c|c|c|c|c|c|}
\hline Short vowels & Allophones & Contexts & Examples & $\begin{array}{c}\text { Long } \\
\text { vowels }\end{array}$ & Allophones & Contexts & Examples \\
\hline \multirow{3}{*}{$/ \mathrm{a} /$} & [æ] & $\begin{array}{c}\text { except in diphthong } \\
\text { /aj/ }\end{array}$ & cat, out & \multirow{3}{*}{ /a:/ } & \multirow{3}{*}[\mathrm{a}:]{} & \multirow{3}{*}{ all contexts } & \multirow{3}{*}{ father, star } \\
\hline & {$[\mathrm{a}]$} & diphthong /aj/ & by & & & & \\
\hline & [a] & $\begin{array}{c}\text { diphthongs /aj/ and } \\
\text { /aw/ }\end{array}$ & by, out & & & & \\
\hline \multirow{2}{*}{ /e/ } & {$[\varepsilon]$} & all contexts & red, play & & & & \\
\hline & [e] & in diphthong /ej/ & play, state & & & & \\
\hline \multirow{2}{*}{ /i/ } & {$[\mathrm{I}]$} & all contexts & pit & \multirow{2}{*}{ /i:/ } & [i:] & $\begin{array}{l}\text { except before /r/ } \\
\text { and /R/ }\end{array}$ & fee \\
\hline & [i] & $\begin{array}{l}\text { before vowels and in } \\
\text { final position }\end{array}$ & $\begin{array}{c}\text { geology, } \\
\text { happy }\end{array}$ & & [เәح] & before $/ \mathrm{r} /$ and $/ \mathrm{R} /$ & fear, fearing \\
\hline \multirow{2}{*}{ /o/ } & {$[\mathrm{p}, \mathrm{o}]$} & except before /R/ & pot, sorry & \multirow{2}{*}{ /o:/ } & \multirow{2}{*}[0:0:]{} & \multirow{2}{*}{ all contexts } & \multirow{2}{*}{ caught, all, sport } \\
\hline & {$[0]$} & in diphthong /oj/ & voice & & & & \\
\hline \multirow[t]{2}{*}{$/ \mathrm{u} /$} & {$[\mho]$} & all contexts & foot, pull & \multirow[t]{2}{*}{ /u:/ } & [u:, u:] & $\begin{array}{l}\text { except before /r/ } \\
\text { and /R/ }\end{array}$ & food, super \\
\hline & {$[\mathrm{u}, \mathrm{u}]$} & before vowels & influence & & [णอ] & before $/ \mathrm{r} /$ and $/ \mathrm{R} /$ & pure, fury \\
\hline \multirow{3}{*}{$/ \mathrm{A} /$} & {$[\Lambda, \mathrm{e}]$} & all contexts & $\begin{array}{c}\text { hut, hurry, } \\
\text { undo }\end{array}$ & \multirow{3}{*}{$/ \Lambda: /$} & \multirow{3}{*}{ [3:] } & \multirow{3}{*}{$\begin{array}{c}\text { all contexts (most } \\
\text { frequent before /r/ } \\
\text { and /R/ }\end{array}$} & \multirow{3}{*}{$\begin{array}{l}\text { furry, hurt, hors- } \\
\text { doeuvre }\end{array}$} \\
\hline & {$[\partial, \mathrm{i}]^{3}$} & unstressed syllable & animal, apron & & & & \\
\hline & [อ] & diphthong / $/ \mathrm{w} /$ & go, low & & & & \\
\hline Semivowels & Allophones & Contexts & Examples & & & & \\
\hline \multirow{3}{*}{$\mid \mathrm{j} /$} & [j] & before vowels & yes & & & & \\
\hline & [I] & $\begin{array}{c}\text { after vowels, except } \\
\text { before } / \mathrm{r} / \text { and } / \mathrm{R} /\end{array}$ & play, pain & & & & \\
\hline & [ə] & $\begin{array}{c}\text { after vowels, before } \\
\text { /r/ and /R/ }\end{array}$ & fairy, their & & & & \\
\hline \multirow{2}{*}{$/ \mathrm{w} /$} & [w] & before vowels & wine, queen & & & & \\
\hline & {$[0]$} & after vowels & out, low & & & & \\
\hline
\end{tabular}

\section{Vowel Clusters}

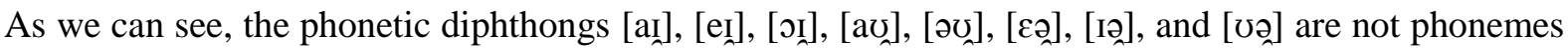
but clusters of a vowel phoneme and a semivowel. Fundamentally, the six English short vowels present different allophones as they occur alone or followed by $/ \mathrm{j} /$ or $/ \mathrm{w} /$. These glides, in turn, also present different allophones as they are before ([j] or $[\mathrm{w}]$ ) or after the vowel ([I] or [j]), forming, therefore, a rising or falling diphthong. The semivowel $/ \mathrm{j} /$ also has an allophone [ə] in coda position when followed by the phoneme $/ \mathrm{r} /$ (pronounced [r]) or the archiphoneme $/ \mathrm{R} /$, which neutralises $/ \mathrm{r} /$ and $\varnothing$.

How to prove it? Let be the words let [let], lay [leI], and lair [leə(I)]. Hence we assume, in the mainstream approach, the alleged phonemes /ě/ (or/e/), /â/ (or /ei/), and /â/ (or /eə/). It is easy to see that the phonetic sequence [عə] only occurs before $/ \mathrm{r} /$ and $/ \mathrm{R} /(* / \mathrm{leat} / \mathrm{and} * / \mathrm{lea} / \mathrm{are}$ impossible in English), while /e/ and /eI/ never occur before $/ \mathrm{r} /$ and $/ \mathrm{R} /\left(* / \mathrm{le}(\mathrm{I}) /^{4}\right.$ and $* / \mathrm{le}(\mathrm{I}) /$ are equally impossible). We say that /es/ and /eə/ have complementary distribution, therefore, they are, in principle, combinatorial allophones of the same phoneme. Incidentally, there is a historical explanation for this. At some point in the evolution of Middle English, the free $a$ became long and then began to move forward and progressively diphthongise, merging with the diphthong ai. We then had something like /a/ $>/ \mathrm{a}: />/ \mathfrak{x}: />/ \varepsilon: />/ \varepsilon \mathrm{I} />/ \mathrm{e} /$. One can imagine that at some point Mary and fairy sounded ['meıii] and ['fenii]. As the retroflex [I] of English causes the lowering of the previous vowel as a matter of phonetic harmony or assimilation, the semivowel [I] lowered to [ə], a fact for which undoubtedly contributed the neutralisation of $/ \mathrm{I} /$ and $/ \partial /$ in unstressed position. This means that every /ea/ was once /eI/.

If, therefore, these two diphthongs have complementary distribution, /e/ and /es/, on the contrary, are

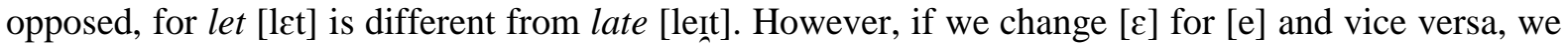
seem to have no change of meaning (the pronunciations [let] of let and [lert] of late do exist,

\footnotetext{
${ }^{3}$ The vowel [i] can equally be considered as an unstressed allophone of /i/; however, I prefer to consider it an allophone of $/ \Lambda /$, since, in the contexts where [i] occurs, [ə] occurs as well, but not always [I]. In contrast, in the contexts where [I] alternates with [i], it also alternates with [ə], so that [i] seems to be distributionally closer to [ə] than to [I].

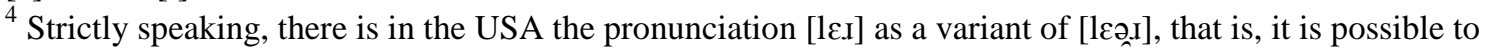

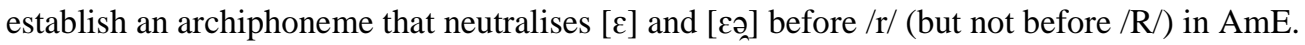


especially in Great Britain and Australia, although in certain places only $[\varepsilon]$ is used and in others only [e]). Yet, the most common in both RP and GA is that [e] is only found in the cluster [eI] and that $[\varepsilon]$ does not occur followed by [I]. It follows that /eI/ is not a phoneme, but the combination of /e/ and the semivocalic /I/, which also occurs in /aI/ and /oI/. Next, we find that [j] and [I] have complementary distribution, since [j] only occurs before vowel and [I], only after vowel. That is, [j] and [I] are combinatorial allophones of the same phoneme / $\mathrm{j} /$ as they are in onset or coda position in the syllable. It follows that [eI] does not correspond to one phoneme, but two: /e/ and $/ \mathrm{j} /$. It also follows that the cluster [ $\varepsilon$ a], which we had proved to be a variant of [eI] , is not a phoneme, but the same combination $/ \mathrm{e} /+\mathrm{j} /$, where the phoneme $/ \mathrm{j} /$ sounds like [ə] before $/ \mathrm{r} /$ and $/ \mathrm{R} /{ }^{5}$. In short, we have the following phonemes and their allophones:

- $\quad / \mathrm{e} / \sim[\varepsilon]$ and $[\mathrm{e}]$ (free allophones in some English varieties and combinatorial in others);

- $\quad / \mathrm{j} / \sim[\mathrm{j}],[\mathrm{I}]$, and [ə] (combinatorial allophones).

The same reasoning applied to /j/ and its allophones is true for $/ \mathrm{w} /$ and its allophones [w] (in onset position) and [0] (in coda position).

As for the other diphthongs, the same glides $/ \mathrm{j} /$ and $/ \mathrm{w} / \mathrm{can}$ be abstracted, alongside with the short

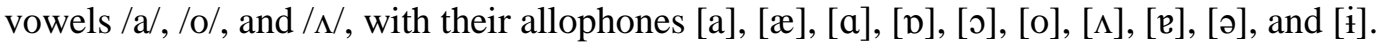

On the diphthong [əơ] of $\mathrm{BrE}$, we conventionally represented it phonologically as $/ \Lambda \mathrm{W} /$, but the fact that it is pronounced as [ov] in other varieties of English, including some of Great Britain, could allow us to represent it as /ow/. In this case, [ə] would be the allophone of $/ \mathrm{o} / \mathrm{before}$ the semivowel $/ \mathrm{w} /$. However, since [ə] is an allophone of $/ \mathrm{N} /$, we chose the simplest representation.

As for the alleged triphthongs of the mainstream approach, we actually have the combination of a diphthong plus $/ \mathrm{\partial} /$, hence three phonemes: /aj $\Lambda /$, /ej $\Lambda /$, $/ \mathrm{oj} \Lambda /$, /aw $/$, / $/ \Lambda \mathrm{W} N /$ (/ow $/$ in AmE). On the representation of [ə] as $/ \mathrm{N} /$, we will speak later on (see item $S c h w a$ ).

\section{Vowels $i$ and $u$}

In relation to /i/ (i.e. short $i$ ), we have two allophones: [I], which is the 'normal' realisation of the vowel, and [i], which occurs in unstressed position before another vowel (e.g. in geology [dzi' plədzi] and in absolute final position, as in geology, happy, etc.

In final position, the mainstream approach sometimes considers [i] a phoneme distinct from [I], using to support such a position minimal pairs such as studded ['st $\Lambda \mathrm{did}$ ] vs. studied ['st $\Lambda \mathrm{did}$ ] and taxes ['tæksız] vs. taxis ['tæksiz]. However, the postulation of a phoneme that occurs only in final position, followed or not by /d/ or /z/ is quite uneconomical (not to say unreasonable) in terms of phonological yield (cost of opposition vs. number of minimal pairs). Moreover, the pronunciations [dzI'pladzi], ['hæpI], ['st $\Lambda$ dr] , and ['tæksI] also occur [15], and the substitution of [i] for [I] in these cases does not entail any change of meaning. In pop music lyrics, by the way, it is common to hear a word like baby pronounced ['berbe], in which the final [e] is an exaggeratedly open manner of pronouncing [I]. Kreidler [16], McCully [17] and Roach [18] suggest that [i] occurs in contexts where the neutralisation of $/ \mathrm{I} /$ and $/ \mathrm{i}$ :/ takes place, and, thus, is an archiphoneme. However, in final position, especially in the BrE variety, it cannot be said that there is such a neutralisation because there are a number of words (caries, series, species, etc.) in which the ending /i:z/ sounds different from /iz/ (compare caries vs. carries or chickaree vs. chicory) [19], [20].

In addition, it should be noted that the ending [iz] occurs only in the plural of nouns ending in $i$, ie, or $y$ (taxis, calories, theories) and in the third person singular present indicative of verbs ending in $y$ (carries, copies, etc.). The ending [id] only occurs in the past and participle of regular verbs ending in $y$ (carried, copied, etc.). The pronunciation of the plural or third person singular ending es after sibilant consonant $(/ \mathrm{s} /, / \mathrm{z} /, / \mathrm{J} /, / \mathrm{t} /, / \mathrm{d} / \mathrm{s} /)$ is always [Iz], as well as the pronunciation of the past/participle ending -ed after dental stop (/t/, /d/) is always [Id]. That is, the pronunciations [iz] and

\footnotetext{
${ }^{5}$ As a result, the neutralisation $[\varepsilon] \sim[\varepsilon{ }]$ referred to in the previous footnote can be formally translated as /e/ /ej/ / _ / $/ \mathrm{r}$, that is, there would be in AmE an archiphoneme $/ \mathrm{J} /=/ \mathrm{j} / \sim \varnothing$ so that the word lair would be transcribed as /leJr/. In BrE, the transcription would be /lejR/, that is to say, in Britain it is optional to realise /r/, whereas in the USA it is the realisation of yod (in its allophone [ə]]) which is optional.
} 
[id] seem to occur by analogy to the forms ending in [i], of which they are inflections. In fact, the pronunciations ['kppI], ['kppiz] are also found and there is no change of meaning in them.

We can say, therefore, that the oppositions studded vs. studied and taxes vs. taxis are not of phonological but morphological nature, since they correspond to a different segmentation of the morphemes: studd-ed/'st $\Lambda \mathrm{d}-\mathrm{id} / \mathrm{vs.}$ studi-ed/'st $\Lambda \mathrm{di}-\mathrm{d} /$, tax-es /'taks-iz/ vs. taxi-s /'taksi-z/. In this case, we would say that the allophone [i] occurs in unstressed end of morpheme and [I] in the other contexts.

In short, the phoneme /i/ presents the allophones [I] and [i], which are not to be confused with the phoneme /i:/. Analogously, the phoneme /u/ has the allophones $[v]$ and $[\mathrm{u}]$ (which can also be pronounced $[\mathrm{u}]$ ) in the same contexts: $[\mathrm{u}]$ or $[\mathrm{u}]$ before vowel (influence, usual) and $[\mho]$ in other contexts, except in final position, where only/u:/ occurs (residue).

The long vowels /i:/ and /u:/ have their respective allophones [ı] and [ชə] before /r/ and /R/. The reason is the previously mentioned vowel lowering caused by /r/. The diphthongisation of /i:/ and /u:/ is a purely phonetic process, but we can also analyse it from the phonological point of view, since, in a certain way, $/ \mathrm{i}: /=/ \mathrm{ij} /$ and $/ \mathrm{u}: /=/ \mathrm{uw} /{ }^{6}$. In this sense, there would have been a lowering of $/ \mathrm{j} /$ or, in

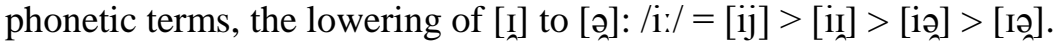

\section{Schwa}

English has the vowel $/ \Lambda$, which comes from an old short $u$ that has been kept in a few words (full, push) and in the others has evolved into a near-open back sound. Currently, many speakers realise $/ \mathrm{N} /$ as a central near-open vowel $[\mathbb{e}]$, although the original pronunciation $[\Lambda]$ remains alive [21]. Although this vowel, like the other full vowels of English, occurs predominantly in stressed syllables, it can also occur in unstressed syllable (undo). In turn, schwa (/o/) occurs, in the BrE variety, exclusively in unstressed syllables and is the result of the reduction of full vowels in unstressed syllable. In fact, in unstressed position, all vowels converge to [ə], [I] or [i] (less often to [ช]). In this sense, cases like undo would be examples of secondary stress (therefore, the syllable un of undo would not be totally unstressed). Ladefoged [22] and Bolinger [23], however, consider this as a mere difference in vowel quality rather than stress. That is the position also taken here.

Anyway, in non-stressed syllables, $[\Lambda]$ and [ə] (and its variant [i]) are not opposed, since [ən' $\mathrm{du}:]$ and [ $\Lambda$ 'baưt] do not mean things other than [ $\Lambda \mathrm{n}^{\prime} \mathrm{du}$ :] and [ə'baơt]. Given that [ə] and its variants never occur in stressed syllable in the BrE variety, it can be said that $[\Lambda]$ and [ə] have complementary distribution and, therefore, they are allophones of the same phoneme. Thus, we posit the phoneme $/ \mathrm{N} /$, whose realisation in stressed syllable is $[\Lambda]$ or [e] (free variants) and in unstressed syllable can be [ə] or [i] (in cases where it may sound [i] - usually in the posttonic syllable - it is neutralised with the phoneme /i/, producing the already mentioned archiphoneme /I/).

On the other hand, the phone [3:], which occurs in general before /r/ and /R/ (but also in other contexts, as in hors-doeuvre and cordon bleu), is potentially opposed to $[\Lambda]$ in stressed syllable (hurry ['h^.ii] vs. furry ['f3:xi]) and actually in unstressed syllable (forward ['fo:wəd] vs. foreword ['fo:w3:d]). As we already know that $[\Lambda]$ and [ə] are allophones of $/ \Lambda$, the opposition, both in stressed and unstressed syllable, occurs between [3:] and $/ \Lambda /$. For simplicity and to maintain the symmetry between short and long vowels, we say that [3:] is the long counterpart of $/ \mathrm{N} /$ and represent it phonologically as $/ \Lambda: /$.

In AmE, as we shall see later on, there is a tendency to pronounce [ə], [ $\Lambda$, and [3:] always as [ə].

\section{Vocalism in the AmE Variety}

Now let us look at the English vocalism in the American variety. In the USA, the main opposition is not between long and short vowels, but between tense and lax vowels. Strictly speaking, since vowel quantity (i.e. duration) is not a relevant distinctive feature, the distinction between vowels is based on their timbre. Therefore, the denomination tense vs. lax does not really have to do with tension or intensity, but with degree of opening and place of articulation. Therefore, I will replace these terms with close and open, respectively. Let us look at Table 4.

\footnotetext{
${ }^{6}$ Proof of this is that $/ \mathrm{i}: /$ and /u:/ are pronounced as [rj] and [ $\left.\mathrm{ww}\right]$ in many places. In some of them, by the way, these diphthongs are already evolving to [ej] and [ow], respectively.
} 
Table4. American English vowel phonemes in the new approach

\begin{tabular}{|c|c|c|c|c|c|c|c|}
\hline Open vowels & Allophones & Contexts & Examples & $\begin{array}{c}\text { Close } \\
\text { vowels }\end{array}$ & Allophones & Contexts & Examples \\
\hline$/ æ /$ & [æ] & $\begin{array}{c}\text { except in } \\
\text { diphthong } \\
\text { /aj/ }\end{array}$ & cat, out & $/ \mathrm{a} /$ & [a] & all contexts & $\begin{array}{c}\text { father, star, } \\
\text { by, pot, } \\
\text { sorry }\end{array}$ \\
\hline \multirow[t]{2}{*}{$\mid \varepsilon /$} & {$[\varepsilon]$} & $\begin{array}{c}\text { except in } \\
\text { diphthong } \\
\text { /ej/ }\end{array}$ & red, there & & & & \\
\hline & [e] & $\begin{array}{c}\text { in diphthong } \\
\text { /ej/ }\end{array}$ & play, state & & & & \\
\hline \multirow[t]{3}{*}{$/ \mathrm{I} /$} & {$[\mathrm{I}]$} & except before & pit, pin & \multirow[t]{3}{*}{ /i/ } & \multirow[t]{3}{*}{ [i] } & \multirow{3}{*}{$\begin{array}{c}\text { except } \\
\text { before /r/ } \\
\text { and /R/ }\end{array}$} & \multirow{3}{*}{$\begin{array}{c}\text { fee, } \\
\text { geology, } \\
\text { happy }\end{array}$} \\
\hline & & vowels & \multirow{2}{*}{$\begin{array}{c}\text { fear, } \\
\text { fearing }\end{array}$} & & & & \\
\hline & [Iอ] & before $/ \mathrm{r} /$ & & & & & \\
\hline \multirow[t]{2}{*}{$/ \mathrm{s} /$} & [0] & $\begin{array}{c}\text { except in } \\
\text { diphthong } \\
\text { /ow/ }\end{array}$ & $\begin{array}{l}\text { caught, } \\
\text { all, sport, } \\
\text { soft, voice }\end{array}$ & & & & \\
\hline & [o] & $\begin{array}{l}\text { in diphthong } \\
\text { /ow/ }\end{array}$ & $\begin{array}{l}\text { go, low, } \\
\text { four }^{7}\end{array}$ & & & & \\
\hline \multirow[t]{3}{*}{$/ \mathrm{J}$} & [v] & except before & \multirow{3}{*}{$\begin{array}{c}\text { foot, pull } \\
\text { pure, fury }\end{array}$} & \multirow[t]{3}{*}{$/ \mathrm{u} /$} & \multirow[t]{3}{*}{ [u:, $\mathrm{u}:]$} & \multirow{3}{*}{$\begin{array}{c}\text { except } \\
\text { before /r/ } \\
\text { and /R/ }\end{array}$} & \multirow[t]{3}{*}{ food, super } \\
\hline & & vowels & & & & & \\
\hline & [णอฺ] & before $/ \mathrm{r} /$ & & & & & \\
\hline & & & & $/ \mathrm{a} /$ & {$[\partial, \Lambda, 3]$} & $\begin{array}{l}\text { stressed } \\
\text { syllable }\end{array}$ & $\begin{array}{l}\text { hut, hurry, } \\
\text { furry, hurt, } \\
\text { hors- } \\
\text { doeuvre }\end{array}$ \\
\hline & & & & & {$[\partial, \mathrm{i}]$} & $\begin{array}{l}\text { unstressed } \\
\text { syllable }\end{array}$ & $\begin{array}{c}\text { undo, } \\
\text { animal, } \\
\text { apron }\end{array}$ \\
\hline Semivowels & Allophones & Contexts & Examples & & & & \\
\hline \multirow[t]{2}{*}{$/ \mathrm{j} /$} & [j] & $\begin{array}{l}\text { before } \\
\text { vowels }\end{array}$ & yes & & & & \\
\hline & [I] & $\begin{array}{l}\text { after vowels, } \\
\text { except before } \\
/ \mathrm{r} / \text { and } / \mathrm{R} /\end{array}$ & play, pain & & & & \\
\hline \multirow[t]{2}{*}{$/ \mathrm{w} /$} & {$[\mathrm{w}]$} & $\begin{array}{l}\text { before } \\
\text { vowels }\end{array}$ & $\begin{array}{l}\text { wine, } \\
\text { queen }\end{array}$ & & & & \\
\hline & [v] & after vowels & out, low & & & & \\
\hline
\end{tabular}

In AmE, the vowels [ə], [ $\Lambda$ ], and [3] have complementary distribution: [ə] in unstressed syllables, $[\Lambda]$ in stressed syllables except before [.] , and [3] in stressed syllables before [ı] [24]. They are, therefore, allophones of a single phoneme / $/$. By the way, many American speakers pronounce [ə] in all three cases.

In BrE, only the long counterpart of /e/ (i.e. */e:/) is missing; the other short vowels have their long counterparts. In AmE, in addition to long /e/, the close counterpart of $/ \mathrm{J} /$ is missing (since [o] is the allophone of $/ \mathrm{J} /$ in the diphthong [ov]) and also the open counterpart of $/ \partial /$. What happens is that, unlike BrE, AmE does not distinguish between [a:] and [ $\mathrm{p}$ ] (it is the so-called father-bother merger), pronouncing both as [a]. In contrast, many words that in BrE sound with [p] (for example, soft and song) sound in AmE with [0]. In other words, the British phonemes /a:/, /o/, and /o:/ undergo a rearrangement in $\mathrm{AmE}$, regrouping into $/ \mathrm{a} /$ and $/ \mathrm{o} /$ : the British phoneme $/ \mathrm{o} /$ is treated in $\mathrm{AmE}$ sometimes as /a:/ (i.e. /a/) and sometimes as /o:/ (i.e./o/).

Similarly, the British vowel /a:/ is often converted into the American /æ/: banana BrE [bə'na:nə]

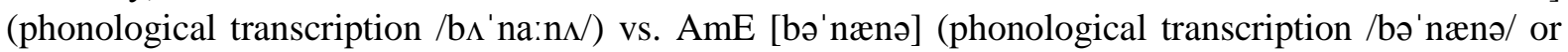
/bı' năn $/$ ).

On the latter transcription, incidentally, if we want to unify the phonological representation of $\mathrm{BrE}$ and AmE varieties, using the same phonetic symbols for both (which would be desirable when it comes to the same language), we can establish the following convention:

\footnotetext{
${ }^{7}$ The word four (and others like it) admits both pronunciations [foun. (sometimes, just [fort]) and [for]. See footnote 2.
} 
Table5. Equivalence of phonemes between British and American varieties of English

\begin{tabular}{|c|c|c|c|c|}
\hline Phoneme & BrE (RP) & Allophones & AmE (GA) & Allophones \\
\hline$/ \breve{a} /$ & $/ \mathrm{a} /$ & {$[\mathrm{a}],[æ],[\mathrm{a}]$} & $/ \mathfrak{/ æ} /$ & {$[æ],[\mathrm{a}]$} \\
\hline$/ \overline{\mathrm{a}} /$ & /a:/ & [a:] & $/ a /$ & [a] \\
\hline$/ \check{\mathrm{e}} /$ & /e/ & {$[\varepsilon],[\mathrm{e}]$} & $/ \varepsilon /$ & {$[\varepsilon],[\mathrm{e}],[\varepsilon \partial]$} \\
\hline$\tilde{\mathbf{1}} /$ & /i/ & [I], [i] & $/ \mathrm{I} /$ & [I], [i], [Iอ] \\
\hline$/ \overline{1} /$ & /i:/ & [i:], [Iอ ] & /i/ & [i:] \\
\hline$/ \check{\mathrm{o}} /$ & $/ \mathrm{o} /$ & [D], [0] & & \\
\hline$/ \overline{0} /$ & 10:/ & [0:] & $/ \mathrm{s} /$ & [0] \\
\hline$/ \breve{\mathrm{u}} /$ & $/ \mathrm{u} /$ & {$[\mho]$} & $/ \sigma /$ & [ひ], [ひə] \\
\hline$/ \overline{\mathrm{u}} /$ & /u:/ & [u:], [ษ:], [və] & $/ \mathrm{u} /$ & {$[\mathrm{u}:],[\mathrm{H}:]$} \\
\hline$\Gamma /$ & $/ \Lambda /$ & {$[\Lambda],[ə],[\mathrm{i}]$} & $/ \partial /$ & {$[\Lambda],[3],[\partial],[\dot{\mathrm{i}}]$} \\
\hline$\overline{\mid \Lambda} /$ & $/ \Lambda: /$ & [3:] & & \\
\hline
\end{tabular}

As we can see, in AmE the diphthongs [ı्]] and [ซə्]], in the varieties in which they occur before $/ \mathrm{r} /$, are not allophones of $/ \overline{\mathbf{1}} /$ and $/ \overline{\mathrm{u}} /$ as in $\mathrm{BrE}$, but of $/ \overline{\mathbf{1}} /$ and $/ \breve{\mathrm{u}} /$, respectively.

\section{Unstressed Syllables and Vowel Reduction}

English has a peculiar feature, which is vowel reduction in unstressed syllable. So much so that the most frequent vowels in this position are [ə] and [I], being [i] a variant of both in contexts in which they are neutralised. The phenomenon of reduction is visible when we compare a pair like photograph vs. photography: in photograph, the first $<_{0}>$ and the $\langle\mathrm{a}\rangle$ are full ([ov], [a:]) while the second $<_{0}>$ is reduced [ə]; in photography, the first $\langle 0\rangle$ and the $\langle a\rangle$ are reduced ([ə]) while the second $\langle 0\rangle$ is full ([p]). The phonological approaches that consider the existence of three degrees of stress in English (primary stress, secondary stress and unstressed syllable) consider that the full vowels occur in primary and secondary stresses and that, therefore, the vowel reduction is exclusive of unstressed syllables. Ladefoged [25] considers that English has only stressed and unstressed syllables, the secondary stress being a phonetic, not phonemic feature.

Considering the existence of vowel reduction could lead us to postulate a series of archiphonemes (for example, $/ \mathrm{A} /=/ \mathrm{a} / \sim / \mathrm{N} /, / \mathrm{O} /=/ \mathrm{O} / \sim / \mathrm{N} /$, etc.) to give account of each of these reductions. Nevertheless, it is simpler to admit, as in many other languages (French, Italian, German, Portuguese) that certain morphemes (e.g. phot- and graph-) admit allomorphs as they are stressed or unstressed (/f $\Lambda \mathrm{wt}-/ \mathrm{vs}$. /f $\Lambda \mathrm{t}-/$, /gra:f-/ vs. /gruf-/). Examples of this type in other languages are: Fr. mener [mé' ne] vs. mène

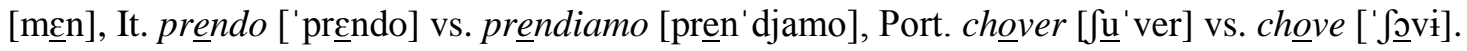

The same applies to most of the monosyllables, which in English have two pronunciations, one stressed and one unstressed: $a$ ([eI] vs. [ə]), an ([æn] vs. [ən]), of ([pv] vs. [əv]), for ([fว:] vs. [fə]), me ([mi:] vs. [mi]), them ([ðعm] vs. [ðəm]), etc.

\section{CONCLUSION}

For a number of reasons (tradition, idiosyncrasy, attachment to orthography), the phonological description of English, especially with regard to vowels, has not followed the usual criteria of phonological theory, as defined by its creators, Jan Baudouin de Courtenay, Mikołaj Kruszewski, Lev Shcherba (1876-1877), Antoni Dufriche- Desgenettes (1873) and especially the linguists of the Prague Linguistic Circle, notably Nikolai Trubetzkoy (Grundzüge der Phonologie, 1939), starting from the distinction between langue (language) and parole (speech), proposed by Ferdinand de Saussure (1916), which theory, by the way, has been little altered in its general principles by more recent approaches (generative, auto segmental, evolutionary phonology, etc.).

The description of English vocalism currently in use considers vowel clusters composed of two phonetic sounds (phones), or sometimes up to three, as a single vowel, as well as considers sounds or clusters of sounds having complementary distribution as if they were distinct phonemes. In this paper, I tried to show that the elimination of these methodological inconsistencies leads to a much simpler description of English, with a smaller number of vowel phonemes, and in which each vowel or semivowel is a phoneme, that is, phonetic diphthongs correspond to phonological diphthongs and not to single phonemes. 
For example, in the current approach, [aI], [eI] and [oI] are seen as three phonemes, despite the recurrence of the final glide [I] and despite [a], [e] and [0] occurring autonomously. In addition, the phonological representation of these alleged phonemes as /aI/, /ei/ and /ol/ is inappropriate in that each phoneme should be represented by a single International Phonetic Alphabet symbol. (For that reason, incidentally, the phonological representation of the affricates $[\mathrm{t} J]$ and $\left[\mathrm{d}_{3}\right]$ is done internationally with the symbols $/ \mathrm{t} /$ and $/ \mathrm{d} /$ or, failing them, with $/ \widehat{\mathrm{t}} /$ and $/ \widehat{\mathrm{d}_{3}} /$.)

It is a fact that the pseudophonemes /ai/ and /ei/ come historically from the simple Old English vowels $\bar{l}$ and $\bar{a}$ (/ऽI/ was borrowed directly from French in this form), but the fact that a current diphthong comes from an old monophthong does not make necessarily this diphthong a single phoneme. Proof of this is that the Latin long $\bar{e}$ has evolved in modern French to <oi> (pronounced [wa]), but the descriptions of the French phonological system do not consider /wa/ a phonemically indivisible unit. In effect, /wa/ is phonologically opposed to /we/, /wi/, etc., and also to /ja/, /la/, /da/, and so on, from which two distinctive units are abstracted, /w/ and /a/.

The fact that the elements [a], [e] and [o] of the pseudophonemes /aI/, /eI/ and /oI/ sound a bit different from the autonomous vowels $[æ],[\varepsilon]$ and [p] does not mean much in phonological terms: the fact that these autonomous monophthongs can also be pronounced as [a], [e] and [0] in certain varieties of the language, as well as the finding that in other varieties the series $[\mathrm{a}] /[\mathrm{e}] /[\mathrm{o}]$ and $[\mathfrak{e}] /[\varepsilon] /[\mathrm{p}]$ have complementary distribution (the first series only in diphthongs and the second only in monophthongs), already prove that they are only combinatorial allophones of the same phonemes. The finding that /eI/ and /ea/ (best represented as /ei/ and /ea/) also present complementary distribution equally leads to the conclusion that they are not two distinct phonemes (actually, they are not even phonemes). The same reasoning applies to all other vowels.

In short, disregarding these facts leads to a more complex phonological description and farther from reality than it should be. I hope, therefore, to have been able to demonstrate in this article that the phonological reality of the English language is much simpler than the available phonological textbooks suggest.

The revision of English phonology, especially in relation to vocalism, will certainly imply the reformulation of the descriptions found in the language dictionaries, which will facilitate not only the understanding of the system by foreign speakers who are learning English as well as the native speakers themselves, who sometimes need to consult the dictionary to learn the correct pronunciation of a particular word, since the official spelling does not help much in these cases.

In this regard, although this study has not been exhaustive in terms of regional allophones and other specifics of the phonetics and dialectology of the language, I hope to have made an important contribution to the studies of phonetics and phonology of English.

\section{REFERENCES}

[1] Coseriu, E. Teoría del lenguaje y lingüística general. $3^{\text {rd }}$ ed. Madrid: Gredos, 1973, pp. 94-9.

[2] Celce-Murcia, M.; Brinton, D.; Goodwin, J. Teaching pronunciation: a reference for teachers of English to speakers of other languages. Cambridge: Cambridge University Press, 1996, pp. 62-7.

[3] Roach, P. English phonetics and phonology: a practical course. 4th ed. Cambridge: Cambridge University Press, 2009, pp. 26-8.

[4] Wells, J. C. Accents of English. Cambridge: Cambridge University Press, 1982, p. 490.

[5] Wells, op. cit., 1982, p. 550.

[6] Ladefoged, P. A course in phonetics. 4th ed. Fort Worth: Harcourt College Publishers, 2001, p. 55.

[7] Cruttenden, A. Gimson's pronunciation of English. London: Hodder Arnold, 2008, p. 230.

[8] McMahon, A. An introduction to English phonology. Edinburgh: Edinburgh University Press, 2002, p. 31.

[9] Giegerich, H. English phonology: an introduction. Cambridge: Cambridge University Press, 1992, p. 36.

[10] Ladefoged, P. Vowels and consonants. Chichester: Blackwell, 2006, p. 68.

[11] Roach, op. cit., 2009, p. 43.

[12] Roach, op. cit., 2009, pp. 100-1.

[13] Kreidler, C. The pronunciation of English. Chichester: Blackwell, 2004, p. 84.

[14] Wells, op. cit., 1982, p. 55. 
[15] Lewis, J. W. HappYl and Reconnoitred. The Home Page of Jack Windsor Lewis (http://www.yek.m e.uk/happyland.html). Access on 21st Aug 2017.

[16] Kreidler, op. cit., 2004, pp. 82-3.

[17] McCully, C. The sound structure of English. Cambridge: Cambridge University Press, 2009, pp. 123-4.

[18] Roach, op. cit., 2009, pp. 66-8.

[19] Wells, J. C. Sounds interesting. Cambridge: Cambridge University Press, 2014, p. 53.

[20] Bolinger, D. Intonation and its parts: melody in spoken English. Redwood, CA: Stanford University Press, 1986, p. "3” 48.

[21] Roca, I; Johnson, W. A course in phonology. Chichester: Blackwell, 1999, p. 135.

[22] Ladefoged, op. cit., 2001.

[23] Bolinger, op. cit., p. "3" 51.

[24] Wells, op. cit., 1982, pp. 121, 132, 480.

[25] Ladefoged, op. cit., 2001, § 5.4; Preliminaries to linguistic phonetics. Chicago: University of Chicago Press, 1980 p. 83.

\section{AUTHOR'S BIOGRAPHY}

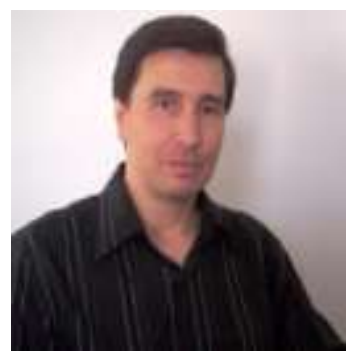

Aldo Luiz Bizzocchi, holds a PhD in Linguistics from the University of São Paulo with postdoctoral degrees in Comparative Linguistics and Etymology. $\mathrm{He}$ is currently a researcher at the Centre for Research in Etymology and History of the Portuguese Language at the University of São Paulo (www.nehilp.org). He is the author of two books and co-author of five other works. He is also devoted to the scientific popularisation of linguistics by means of blogs, articles in magazines and videos on the internet.

Citation: Aldo Luiz Bizzocchi "How Many Phonemes Does the English Language Have?" International Journal on Studies in English Language and Literature (IJSELL), vol 5, no. 10, 2017, pp.36-46. doi:http://dx.doi.org/10.20431/2347-3134.0510006.

Copyright: (C) 2017 Authors. This is an open-access article distributed under the terms of the Creative Commons Attribution License, which permits unrestricted use, distribution, and reproduction in any medium, provided the original author and source are credited. 